\title{
The sand extraction potential of embedded land surface lowering in the Netherlands
}

\author{
M.J. van der Meulen ${ }^{1}$, M.P.E. de Kleine ${ }^{1}$, J.G. Veldkamp ${ }^{1}$, C.W. \\ Dubelaar $^{1,2}$ \& H.S Pietersen ${ }^{3,4}$ \\ ${ }^{1}$ Netherlands Institute of Applied Geoscience TNO, P.O. Box 80015, NL-3508 \\ TA Utrecht, The Netherlands \\ ${ }^{2}$ corresponding author; e-mail: c.dubelaar@nitg.tno.nl \\ ${ }^{3}$ Road and Hydraulic Engineering Institute, P.O. Box 5044, NL-2600 GA Delft, \\ The Netherlands \\ ${ }^{4}$ Delft Technical University, Faculty of Civil Engineering and Geosciences, P.O. \\ Box 5048, NL-2600 GA Delft, The Netherlands
}

Manuscript submitted: May 2003; accepted: January 2004

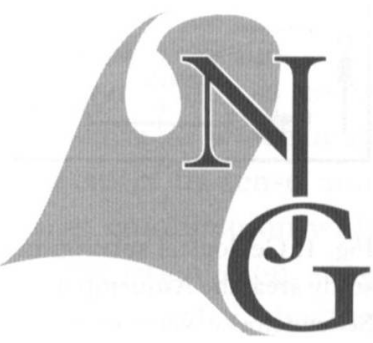

\begin{abstract}
In the Netherlands, mineral extraction by means of dredging or quarrying meets with considerable societal resistance. Land surface lowering prior to large land reconstruction projects may raise fewer objections. We have calculated the potential yields of sand and gravel from land surface lowering embedded in planned building and construction projects, and in nature, farmland and recreation area development. Our primary data sets were a compilation of spatial plans for the period $1995-2005$ and about 95,000 borehole descriptions. Even if embedded consistently, land surface lowering would contribute modestly (up to $5.4 \mathrm{Mio} \mathrm{m}^{3} / \mathrm{a}$ ) to the filling sand provision (annual demand $45-50 \mathrm{Mio} \mathrm{m}^{3} / \mathrm{a}$ ).
\end{abstract}

Keywords: The Netherlands, mineral extraction, spatial planning, land surface lowering, sand, gravel.

\section{Introduction}

Mineral extraction in the Netherlands has met with an ever-increasing societal resistance since the early seventies (Van der Meulen et al., 2003; In press). This especially applies to large-scale coarse sand and gravel extractions which, for geological reasons, are operational or considered in the southeastern half of the country, while a large part of the demand is generated elsewhere. Several lines of policy have been developed to minimize extraction and its effects (Ike \& Voogd, 2000; Anonymous, 2001). These include promotion of the embedding of extraction in any project involving ground work, such as building, construction and water engineering works.

The present paper explores the potential yield of land surface lowering prior to large land reconstruction projects, i.e. building and construction works, nature, farm land and recreation area development, etc. This type of extraction (further referred to as embedded land surface lowering) is expected to raise ferwer objections than traditional extraction, i.e. from dredged pits or open quarries, because the visible impacts are limited and it is undertaken in areas which are already subjected to change. The study (full report in Dubelaar et al., 2001 and Schrauwen et al., 2001) has been commissioned by the Ministry of Transport, Public Works and Water Management, which is responsible for mineral planning guidance in the Netherlands. Results were to be used to assess whether embedded land surface lowering qualifies for active stimulation. This would especially be the case if it were to produce significant amounts of coarse sand and gravel.

Historically, most aggregates were obtained by land surface lowering. It became less popular when the extractive industry adapted more efficient dredging techniques, and eventually banned because of the impacts on the (ground) water system and valued geo- 
morphological features. Policy makers feel that the latter objections do not apply to embedded land surface lowering (Anonymous, 2001).

\section{Relevant projects}

Anonymous (1997) presented a digital compilation of about 2700 planned reconstruction projects for the period $1997-2005$. Our approach has been (1) to calculate the hypothetical yields from land surface lowering embedded in these projects, and (2) to calculate the average annual yield, i.e. the current maximum potential contribution of embedded land surface lowering to the Dutch building raw materials provision.

For many of the projects considered, the local hydrological situation would inhibit embedded land surface lowering. Their shear number, however, precludes the assessment of the possibilities per case. Therefore a selection has been made using generic criteria. Land surface lowering is only considered an option on the so-called higher grounds in the eastern and southern parts of the country. The study area excludes all dike-protected lowlands and polders, where land surface lowering would bring about an increased flooding risk or impose water management problems. On the higher grounds, the local ground water situation has been used for a final project selection. The only suitable ground water data set is provided by De Vries \& Denneboom (1992), who have mapped eight water table classes throughout the country (Table 1 ).

Table 1. Water table classes used for hydrological mapping in the Netherlands (De Vries \& Denneboom, 1992).

\begin{tabular}{ccc}
\hline \multirow{2}{*}{$\begin{array}{c}\text { Water table } \\
\text { Class }\end{array}$} & \multicolumn{2}{c}{ Mean phreatic ground water table } \\
Annual minimum $(\mathrm{cm})$ & Annual maximum $(\mathrm{cm})$ \\
\hline I & & $<50$ \\
II & & $50-80$ \\
III & $<40$ & $80-120$ \\
IV & $>40$ & $80-120$ \\
V & $<40$ & $>120$ \\
VI & $40-80$ & $>120$ \\
VII & $>80$ & $>120$ \\
VIII & $>140$ & $>140$ \\
\hline
\end{tabular}

We have only considered land surface lowering in areas with water table classes VII and VIII. Elsewhere, it would either be impossible, require enhanced water management, or be insignificant in terms of yield (Table 2).

Infra-structural projects have not been taken into consideration. A pre-screening of the data revealed that only limited stretches of planned road or railway trajectories cross areas suitable for land surface lowering. Any yields would probably be re-used elsewhere in the same projects.
Table 2. Types of projects considered in the study area, clipped to water table class VII and VIII areas. Note: cases refer to polygons in the digital data set and do not necessarily equal reconstruction projects (2700 in number).

\begin{tabular}{lrr}
\hline Development of: & Nr. of cases & Area $\left(10^{3} \mathrm{~m}^{2}\right)$ \\
\hline Production forests & 80 & 909 \\
Nature & 1,690 & 35,102 \\
Farmlands & 55 & 1,176 \\
Building projects & 1,113 & 23,937 \\
Recreational areas & 935 & 8,621 \\
Total & 3,873 & 69,746 \\
\hline
\end{tabular}

\section{Materials considered}

In most of the study area, sand is the predominant near-surface sediment (Dubelaar \& Veldkamp, 1999; Weerts et al., 2000). In the context of application possibilities, grain size is the most important quality parameter of aggregate materials. We distinguish between fine sand, which can be used as filling material, and coarse sand, which can be used as or processed into an aggregate for more advanced purposes (Table 3). Neither the quality of our data, nor the scale of our inventory allows for an assessment based on more material properties, as would be required for feasibility studies for individual cases. For the same reason, we have not distinguished between different kinds of gravel: any type is expected to qualify as a building raw material. Finally, the applications and yields of materials other than sand or gravel (i.e. clay, silt, peat, variegated soil material) have not been considered. Silts and clays, for instance, may be suitable raw materials for the structural ceramic industry. Such an assessment, however, can not be based on geological data alone (Van der Meulen et al., in press).

Lithological information and grain size data have been obtained from DINO, a digital archive of subsurface data developed and maintained by the

Table 3. Materials considered in this study. The 'other' category includes peat, silt, clay and variegated soil material. M63 is the median grain size of the sand fraction $(63-2000 \mu \mathrm{m})$. Definitions are cf. Anonymous $(1989 ; 1990)$.

\begin{tabular}{lll}
\hline Material & Definition & Applications \\
\hline $\begin{array}{l}\text { Fine sand } \\
\text { Coarse sand }\end{array}$ & $\begin{array}{l}M 63<210 \mu \mathrm{m} \\
M 63 \geq 210 \mu \mathrm{m}\end{array}$ & $\begin{array}{l}\text { Fill and foundation material } \\
\text { Production of concreting and } \\
\text { masonry sand, sand for } \\
\text { drainage media etc. } \\
\text { Unknown }\end{array}$ \\
$\begin{array}{l}\text { Sand, M63 } \\
\text { unknown }\end{array}$ & - & $\begin{array}{l}\text { Production of aggregates for } \\
\text { Gravel }\end{array}$ \\
particles $\geq 2 \mathrm{~mm}$ & $\begin{array}{l}\text { concrete and various } \\
\text { unbound applications } \\
\text { None/ unknown }\end{array}$ \\
\hline
\end{tabular}


Table 4. Geological zones in the study area. In brackets: the aggregate surface area of reconstruction projects considered within each zone, in $10^{3} \mathrm{~m}^{2}$.

\begin{tabular}{|c|c|c|}
\hline $\mathrm{Nr}$ & Name & Main lithologies down to $5 \mathrm{~m}$ below the surface \\
\hline 1 & Drenthe plateau $(16,306)$ & Boulder clay (till) covered by fine sand and silt \\
\hline 2 & Hunze valley and Westerwolde $(6,506)$ & Silty fine sands partly underlain by boulder clay \\
\hline 3 & Emmerschans ice pushed ridge (97) & Coarse grained fluvial sands and fluvio-glacial deposits \\
\hline 4 & Vecht valley $(2,327)$ & Fine sands on coarse grained fluvial sands \\
\hline 5 & Salland $(1,666)$ & Gravelly coarse grained sands covered by fine sands \\
\hline 6 & Twente $(2,329)$ & Silty fine sands with intercalations of boulder clay \\
\hline 7 & Achterhoek and Montferland $(1,573)$ & Silty fine sands on boulder clay and coarse grained fluvial sands \\
\hline 8 & Slope deposits along Veluwe ice pushed ridge (758) & Gravelly coarse grained fan deposits \\
\hline 9 & Veluwe ice pushed ridge / Gelderland valley $(2,644)$ & Gravelly coarse grained fluvial sands, partly covered by fine sands \\
\hline 10 & Utrecht ice pushed ridge (839) & Gravelly coarse grained fluvial sands \\
\hline 11 & Nijmegen ice pushed ridge (444) & Gravelly coarse grained fluvial sands \\
\hline 12 & Central and northeastern Limburg $(10,203)$ & Coarse fluvial sands and gravel partly covered by fine sands \\
\hline 13 & Peel Horst High $(6,332)$ & Gravelly coarse grained sands covered by fine sands \\
\hline 14 & Roer Valley Graben $(13,987)$ & Fine sands and loam \\
\hline 15 & Kempen High border zone $(2,240)$ & Coarse grained gravelly fluvial sands \\
\hline 16 & Kempen High (606) & Silty fine sands on fluvial sands and clays \\
\hline 17 & Southern Limburg (889) & Silty fine sands (löss) on a substrate of limestone or sand and gravel \\
\hline
\end{tabular}

Netherlands Institute of Applied Geoscience TNO (the Dutch Geological Survey). DINO contains about 380,000 borehole descriptions, 94,800 of which located in the study area. In most cases, sand descriptions include estimated or measured M63 values (see caption of Table 3 for explanation).

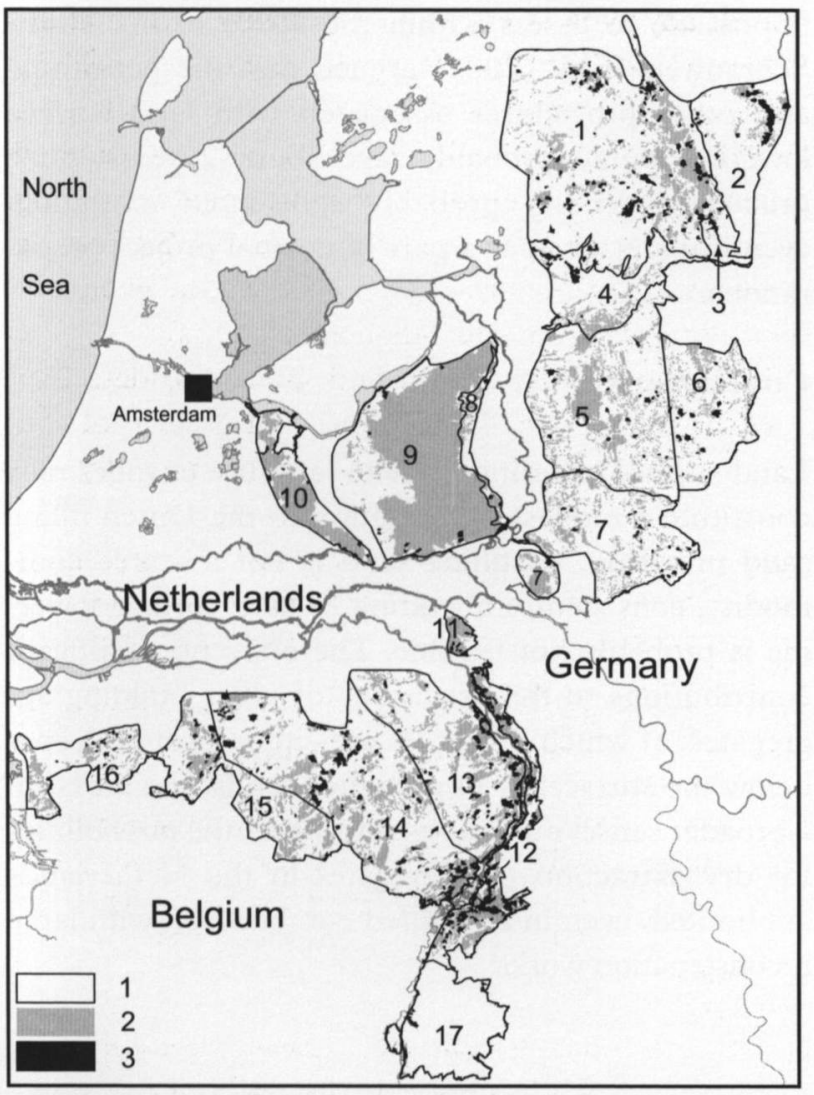

Fig. 1. (1) The study area divided in 17 geological zones (see Table 4), (2) water table class VII and VIII areas, and (3) reconstruction projects considered. See text for explanation.

\section{Geological zonation, data screening}

We have defined seventeen approximately homogeneous geological zones for the purpose of yield assessments (Fig. 1, Table 4). Each has a more or less constant suite of lithological units in the upper meters of the subsurface and, hence, a more or less constant composition. The zones are either glacio-tectonic units (ice-pushed ridges), tectono-stratigraphic units (e.g. Peel Horst High or Roer Valley Graben), or have been formed in distinct physiographic settings (e.g. in valleys, on plateaus).

As a further refinement of our zones, we have screened individual polygons of the geological map of the Netherlands (Weerts et al., 2000) for suitability for land surface lowering. The attribute 'unsuitable' was given in case of surficial or shallow occurrences of predominantly non-aggregate or fine grained materials (e.g. the löss deposits of Southern Limburg; area 17, Fig. 1, Table 4). Projects and borehole data within 'unsuitable' polygons were excluded from further analysis. The final project selection, clipped to water table class VII en VIII areas and 'suitable' polygons, is shown in Fig. 1.

\section{Results and discussion}

Fig. 2 shows the averaged soil composition of $1 \mathrm{~m}$ intervals down to $5 \mathrm{~m}$ below the surface, calculated from the selected borehole data. Yields per meter land surface lowering within each geological zone were obtained by multiplying the aggregate surface area of the selected projects, with the shares of the materials considered. Obviously, these results are averages which do not apply per project. 

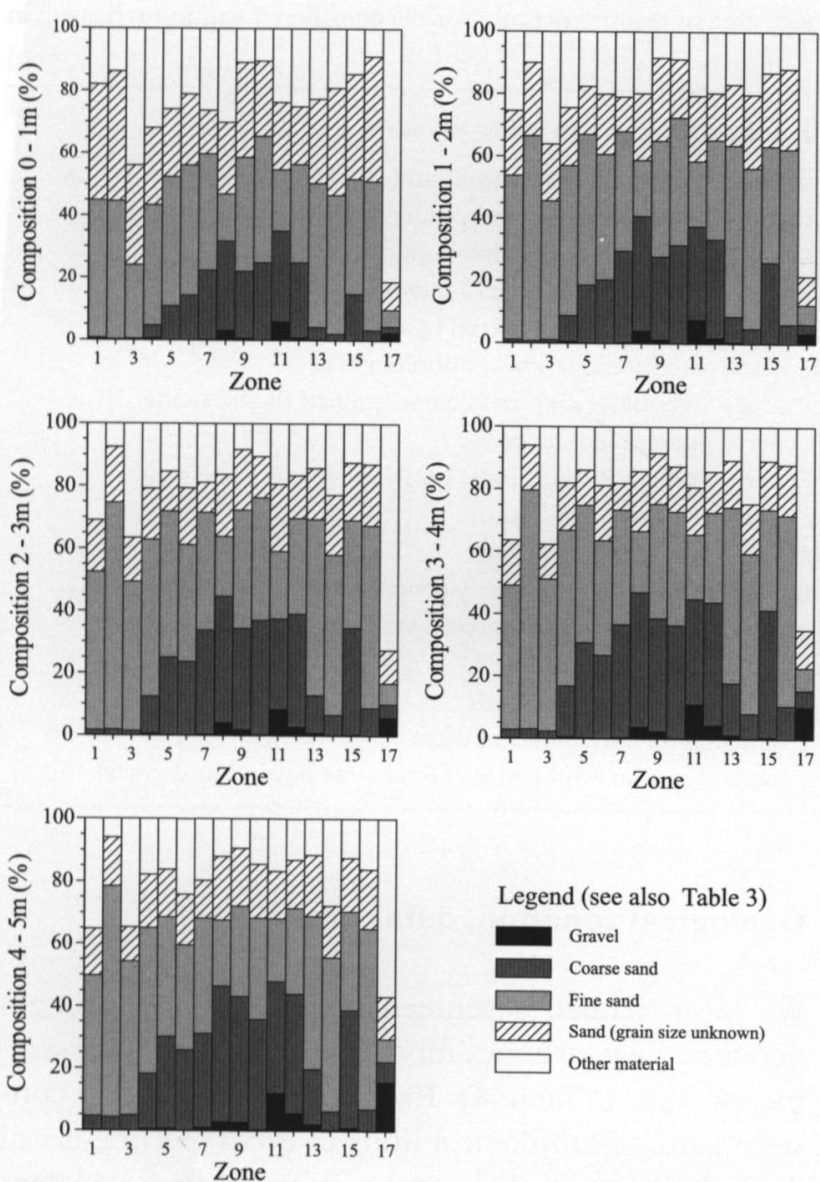

Legend (see also Table 3)

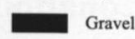

Coarse sand

$\square$ Fine sand

VIIA Sand (grain size unknown)

$\square$ Other material

Fig. 2. The average composition of the soil per geological zone, in 1 $\mathrm{m}$ intervals down to $5 \mathrm{~m}$ below the surface. Note that the share of coarse-grained material increases with depth.

We expect the average amount of land surface to be about $1 \mathrm{~m}$, as approx. $93 \%$ of the aggregate project surface area has ground water table class VII. The yield from such lowering does not necessarily equal the soil composition of the upper meter of the project area. Most land reconstruction activities would already be associated with some ground work, such as the removal of the uppermost soil and reshuffling of material within the project area. We therefore used the average composition of the upper two meters of soil in yield calculations. Land surface lowering of $1 \mathrm{~m}$, embedded in the entire selection of projects, would yield about $56 \mathrm{Mio}^{3}$ of aggregates. The larger part of this volume is fine sand $\left(31 \mathrm{Mio}^{3}\right)$. Yields of coarse sand and gravel would be 6.8 and $0.3 \mathrm{Mio} \mathrm{m}^{3}$, respectively. The share of sand of unknown grain size is about $18 \mathrm{Mio}^{3}$; we expect most of this to be fine grained.

Error margin estimates for these results would have to address the quality of the borehole data, and the implicit assumption of a homogeneous distribution of reconstruction projects over the geological zones. As we have no quantification of the data quality, we approximate the error margins of the yields of sands and gravel with the standard deviation of their shares per zone. We arrive at a error margin of about $37 \%$ for the total yield, and the yields of coarse and fine sand. The margin for gravel is over $100 \%$.

Hypothetical yields from land surface lowering embedded in the projects considered would be generated in a period of 9 years $(1997-2005)$. At an average lowering of $1 \mathrm{~m}$, the maximum current annual potential yield of fine sand (including sand of unknown grain size) is about $5.4 \mathrm{Mio}^{3}$. This amounts to approx. $11 \%$ of the national filling sand demand (45$50 \mathrm{Mio} \mathrm{m}^{3}$ /a; Van der Meulen et al., In press). Even when considering the error margins, the annual maximum yields of coarse sand $\left(0.8 \mathrm{Mio} \mathrm{m}^{3} / \mathrm{a}\right)$ and gravel $\left(<0.1 \mathrm{Mio} \mathrm{m}^{3} / \mathrm{a}\right)$ are minor compared to their annual demands (12 and $10 \mathrm{Mio} \mathrm{m}^{3} / \mathrm{a}$ respectively) and negligible when considering the feasibility aspect. As it turns out, coarse grained deposits at or near the surface mainly occur in protected landscape areas, where land-use change (other than nature development) is restricted. This applies especially to the ice-pushed ridges (zones $8-11$, Table 4, Fig. 1).

We do not elaborate on the possibility of deeper extraction in projects in ground water table class VIII areas. The feasibility of embedding per project is probably a far more limiting factor than the ground water situation or other technical considerations, but impossible to assess within the scope of our study. Schrauwen et al. (2001) argued that the permitting and other procedures associated with land surface lowering would probably take about 2 years. Such procedure time is probably considered inhibiting, even if undertaken as a part of normal project preparations.

\section{Conclusions}

Land surface lowering prior to land use changes may constitute a modest contribution to the Dutch filling sand provision. As filling sand is not a scarce commodity, consistent embedding of land surface lowering is probably not feasible. There are no significant contributions to the provisions of other building aggregates, of which resources are either located deeper below the surface, or in protected landscape areas. In a broader sense, our results imply that the possibilities for dry extraction of aggregates in the Netherlands are limited, even in a planned combination with large reconstruction works. 


\section{Acknowledgements}

The authors wish to thank A. Veldkamp and an anonymous reviewer for comments and suggestions. The work has been commissioned by the Ministry of Transport, Public Works and Water Management, Road and Hydraulic Engineering Institute (project GSV/Maaiveldverlaging; contract DWW 1730).

\section{References}

Anonymous, 1989. NEN 5104:1989, Geotechnics; Classification of unconsolidated soil samples. Netherlands Normalization Institute (NEN; Delft, NL): 24 pp.

Anonymous, 1990. NEN 5104:1989/C1, Geotechnics; Classification of unconsolidated soil samples (amended). Netherlands Normalization Institute (NEN; Delft, NL): 1 pp.

Anonymous, 1997. De Nieuwe Kaart van Nederland (Digital geographical data and technical documentation). Bridgis BV (Tiel, NL).

Anonymous, 2001. 2e Structuurschema Oppervlaktedelfstoffen, Deel 1, Ontwerp Planologische kernbeslissing (in Dutch). Ministerie van Verkeer en Waterstaat (The Hague, NL): $280 \mathrm{pp}$.

De Vries, P. \& Denneboom, J. 1992. De bodemkaart van Nederland digitaal (Digital geographical data and technical documentation, in Dutch), DLO Staring Centrum (Wageningen, NL).

Dubelaar, C.W. \& Veldkamp, J.G., 1999. Toelichting op de zandkaarten van Nederland. Netherlands Institute of Applied Geoscience TNO (Utrecht, NL). Unpublished TNO-Report NITG 99-113-B.

Dubelaar, C.W., Ebbing, J.H.J., Gunnink, J.L., De Kleine, M.P.E., Kloosterman, F.H., Klijnstra, B., Marges, V.C., Van Ruiten, A.C.T., Veldkamp, J.G. \& Van der Meulen, M.J., 2001. Maaiveldverlaging en winning van oppervlaktedelfstoffen (in Dutch). Road and Hydraulic Institute (Delft, NL), report DWW-2001070 / Publicatiereeks Grondstoffen 2001/09: 45 pp.

Ike, P. \& Voogd, H., 2000. Nieuwe wegen voor het ontgrondingenbeleid (In Dutch). Road and Hydraulic Institute (Delft, NL), report W-DWW-2000-069 / Publicatiereeks Grondstoffen 2000/04: $87 \mathrm{pp}$.

Schrauwen, F.M.R., Muskens, M.J., Wiggers, A.G. \& Van der Meer, M.B., 2001. Oppervlaktedelfstoffenwinning uit maaiveldverlaging O.D.M. (in Dutch). Road and Hydraulic Institute (Delft, NL), report DWW-2001-071 / Publicatiereeks Grondstoffen 2001/10: 38 pp.

Van der Meulen, M.J., Koopmans, T.P.F. \& Pietersen, H.S., 2003. Construction raw materials policy and supply practices in Northwestern Europe. In: Elsen, J., Degryse, P. (Eds). Industrial Minerals - Resources, Characteristics and Applications. Aardkundige Mededelingen 13:19-30.

Van der Meulen, M.J., Broers, J.W., Hakstege, A.L., Van Heijst, M.W.I.M., Koopmans, T.P.F. \& Pietersen, H.S., In press. Surface Mineral Resources. In: Wong, Th.E., Batjes, D.A.J. \& De Jager, J. (Eds). Geology of the Netherlands. Royal Netherlands Academy of Arts and Sciences (Amsterdam).

Weerts, H.J.T., Cleveringa, P., Ebbing, J.H.J., De Lang, F.D. \& Westerhoff, W.E., 2000. De lithostratigrafische indeling van Nederland - Formaties uit het Tertiair en Kwartair (in Dutch). Netherlands Institute of Applied Geoscience TNO (Utrecht, NL), TNO-Report NITG 00-95-A: 38 pp. 